\title{
Retinal Cell Neoplasm
}

National Cancer Institute

\section{Source}

National Cancer Institute. Retinal Cell Neoplasm. NCI Thesaurus. Code C7061.

A neoplasm arising from the neural retina. This category includes retinoblastoma and retinocytoma. 